\title{
Discovery of Potent, Reversible MetAP2 Inhibitors via Fragment Based Drug Discovery and Structure Based Drug Design - Part 1
}

Zacharia Cheruvallath ${ }^{\mathrm{a}}$, Mingnam Tang ${ }^{\mathrm{a}}$, Christopher McBride ${ }^{\mathrm{a}}$, Mallareddy Komandla ${ }^{\mathrm{a}}$, Joanne Miura ${ }^{\mathrm{a}}$, Thu Ton-Nu ${ }^{\mathrm{a}}$, Phil Erikson ${ }^{\mathrm{a}}$, Jun Feng $^{\mathrm{a}}$, Pamela Farrell ${ }^{\mathrm{b}}$, J. David Lawson ${ }^{\mathrm{c}}$, Darin Vanderpool ${ }^{\mathrm{b}}$, Yiqin Wu ${ }^{\mathrm{b}}$, Douglas R. Dougan ${ }^{\mathrm{d}}$, Artur Plonowski ${ }^{\mathrm{b}}$, Corine Holub ${ }^{\mathrm{b}}$, and Chris Larson ${ }^{\mathrm{b}}$

${ }^{a}$ Medicinal Chemistry, ${ }^{b}$ Biological Sciences, ${ }^{c}$ Computational Sciences, ${ }^{d}$ Structural Biology, Takeda California

\begin{abstract}
Methionine aminopeptidase 2 (MetAP2) is an enzyme that cleaves an N-terminal methionine residue from a number of newly synthesized proteins. Pre-clinical and clinical studies suggest that MetAP2 inhibitors could be used as a novel treatment for obesity. Herein we describe our use of fragment screening methods and structural biology to quickly identify and elaborate an indazole fragment into a series of reversible MetAP2 inhibitors with $<10 \mathrm{nM}$ potency, excellent selectivity, and favorable in vitro safety profiles.
\end{abstract}

Methionine aminopeptidases (MetAPs) are a class of intracellular metalloproteases that catalyze the removal of the N-terminal initiator methionine residue of nascent proteins. ${ }^{1,2}$ There are three known mammalian MetAPs: MetAP1, MetAP2, and MetAP3 (MAP1D). Both MetAP1 and MetAP2 are found in eukaryotes, while prokaryotes express only MetAP1. MetAP2 attracted a lot of attention when it was first identified as a target for the anti-angiogenic natural product fumagillin and its semi-synthetic analog TNP470 (1). ${ }^{3}$ While early drug discovery efforts were focused on analogs of fumagillin, which irreversibly inhibits MetAP2 by covalent modification of the spirocyclic epoxide, several groups reported reversible inhibitors of MetAP2 with anti-proliferative properties (35, Fig.1). ${ }^{4}$

A report from Rupnick et $a l^{5}$ on the significant body weight loss seen when ob/ob mice were treated with TNP-470 spurred interest in this target in new therapeutic areas. Clinical studies using the irreversible MetAP2 inhibitor Beloranib (2) has demonstrated efficacy when dosed s.c. twice weekly. ${ }^{6}$ In this paper, we disclose a fragment-based drug discovery (FBDD) ${ }^{7}$ approach that led to the identification of several potent, selective, orally efficacious and reversible MetAP2 inhibitors.<smiles>CO[C@H]1[C@@H](OC(=O)NC(=O)CCl)CCC2(CO2)[C@@H]1C1(C)O[C@@H]1CC=C(C)C</smiles>

TNP-470 (1)

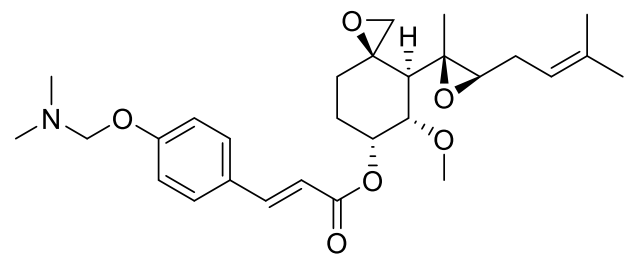

Beloranib (2)<smiles>CC(C)SCCC(N)C(O)C(=O)NNC(=O)c1cccc(Cl)c1</smiles>

Abbott (3)

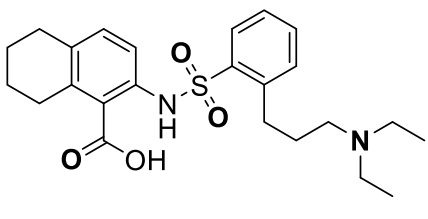

Abbott (4)<smiles>COc1ccccc1C(=O)OC[C@@H]1CCCN1c1ccnc2ncnn12</smiles>

Merck (5)

Fig.1 Structures of selected MetAP2 inhibitors

Our approach began with a biochemical screening of an internal library of $\sim 5000$ fragments (heavy atom count between 11-19 atoms) against MetAP2 ${ }^{8}$ at a concentration of $100 \mu \mathrm{M}$ to identify 110 hits (>20\% inhibition). Ligand efficiency (LE) and lipophilic ligand efficiency (LLE) values for each fragment were estimated using approximate pIC50 $\left(\mathrm{ApIC}_{50}\right)^{9}$ values calculated from the single-point inhibition values of the primary screen. Fragments that had an LE $>0.35$ and an LLE $>4$ were then evaluated by a full dose response curve narrowing the list to 16 interesting fragments.

In this paper we will discuss our efforts to optimize one fragment hit (6). Since the indazole core is a very common fragment, we searched our corporate collection and commercial sources for closely related analogs to assay to build structure activity relationships (SAR). As seen in Fig.2, the hydroxyl group at position 3 (compound 7) was not necessary for potency and in fact larger substituents at position 3 proved to be unfruitful (not reported). Substitution of bromine in compound 7 with an N-methyl pyrazole led to a $>100-$ fold loss in potency (compound 8). Interestingly introduction of an aryl group at position 4 led to compound $\mathbf{1 0}$ with a potency of 24 $\mu \mathrm{M}$. This data suggested that the 4 position of the indazole core may be an important vector to explore. Additionally we found that 
moving the Br substitution from the 6 to the 5 position (compound 7 vs 9) resulted in a 34-fold reduction in potency. Based on this initial SAR, we surmised that the 4 and 6 positions of the indazole were likely to be fruitful to explore and looked to structural information to guide our efforts.<smiles>Oc1n[nH]c2cc(Br)ccc12</smiles>

(6)<smiles>[13CH3][13CH3]</smiles>
LE $=0.69$<smiles>Cn1cc(-c2ccc3cn[nH]c3c2)cn1</smiles>

(8)

IC50 $>100 \mu \mathrm{M}$<smiles>Brc1ccc2cn[nH]c2c1</smiles>

(7)

IC50 $=1.1 \mu \mathrm{M}$ $\mathrm{LE}=\mathbf{0 . 8 1}$<smiles>Brc1ccc2[nH]ncc2c1</smiles>

(9)

LE $=0.61$<smiles>Cn1cc(-c2cc(-c3ccccc3)c3cn[nH]c3c2)cn1</smiles>

(10)

IC50 $=24 \mu \mathrm{M}$

LE $=0.38$

Fig.2 SAR 'by catalog' (corporate collection and commercial sources)

Structural information gathered using X-ray crystallography is a valuable tool that helps drive rapid and iterative design of elaborated compounds in the hit to lead stage of drug discovery. While we were unable to obtain co-xtal structures with fragments from this scaffold, the absence of a co-crystal structure did not preclude progression. To guide our fragment growth efforts, we leveraged key information from the co-crystal structure of compound $\mathbf{3}^{10}$ and from our internal efforts on other fragments and literature MetAP2 inhibitors. Based on a combination of SAR obtained from screening our corporate collection (Fig.2) and available crystallographic information, a putative binding mode for compound 7 was determined by molecular modeling. ${ }^{11}$ It was envisaged that the N2-nitrogen of the indazole ring might coordinate with the active site metal ion. This would orient the bromine atom at position 6 of the indazole ring to fill the adjacent hydrophobic site that is filled by the terminal methionine side chain on the endogenous ligands for MetAP2. Fig.3 shows a model of compound $\mathbf{7}$ (green) overlaid with compound $\mathbf{5}$ (orange) bound to MetAP2. ${ }^{12}$ This docking model and the SAR obtained thus far (compounds 7-10) suggested that an aromatic group at position 4 of the indazole core would potentially fill the narrow hydrophobic cleft between Tyr444 and His339and small hydrophobic groups at position 6 could fill the hydrophobic pocket that is occupied by the bromine atom in the compound 7.

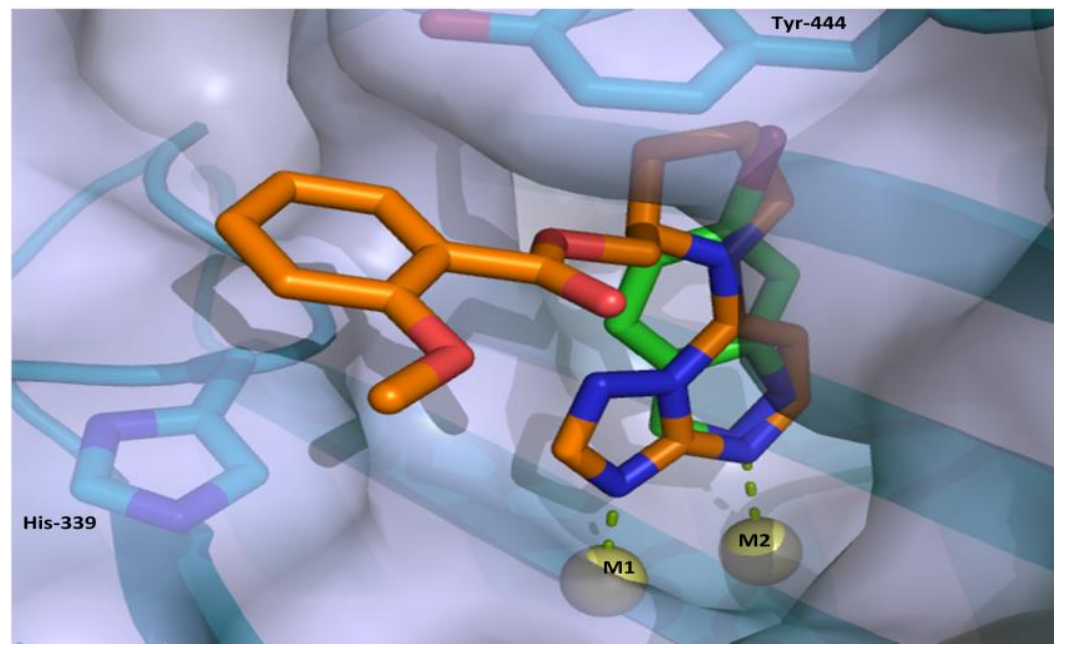

Fig.3. Model of compound 7 (green) overlaid with compound 5 bound to MetAP2

To test our hypothesis we first synthesized compound $\mathbf{1 1}$ using the general synthetic route shown in Scheme 1. Encouraged by the > 300 fold boost in potency of compound $\mathbf{1 1}$ in comparison to compound 10, a small library of compounds (Table 1) were rapidly synthesized to explore the SAR at position 6 of the indazole scaffold. Suzuki coupling of 6-substituted 4-Br indazoles with phenyl 
boronic acid gave the corresponding substituted Indazole derivatives. As seen from the data in Table 1, among the substituents at the 6-position, the trifluoromethyl group (16) gave the best potency and LLE. ${ }^{13}$<smiles></smiles>

Scheme 1 Reagents and conditions: (a) $\mathrm{PdCl}_{2}(\mathrm{dppf})_{2}, \mathrm{Na}_{2} \mathrm{CO}_{3}$, microwave, $130^{\circ} \mathrm{C}$

\begin{tabular}{|c|c|c|c|c|}
\hline Compd & $\mathbf{R}$ & $\mathbf{I C}_{50}(\boldsymbol{\mu M})$ & LE & LLE \\
\hline 11 & $\mathrm{Cl}$ & 0.079 & 0.61 & 3.6 \\
\hline 12 & $\mathrm{H}$ & 5.5 & 0.48 & 2.4 \\
\hline 13 & $\mathrm{~F}$ & 0.96 & 0.52 & 3.0 \\
\hline 14 & $\mathrm{Me}$ & 0.22 & 0.54 & 3.2 \\
\hline 15 & $\mathrm{OMe}$ & 0.73 & 0.50 & 3.4 \\
\hline 16 & $\mathrm{CF}_{3}$ & 0.02 & 0.55 & 3.9 \\
\hline 17 & $\mathrm{CN}$ & 0.062 & 0.58 & 4.5 \\
\hline 18 & $\mathrm{iPr}$ & 0.55 & 0.48 & 2.1 \\
\hline 19 & $\mathrm{MeSO}_{2}$ & 0.36 & 0.47 & 4.7 \\
\hline 20 & $\mathrm{OCF}_{3}$ & 0.091 & 0.48 & 2.7 \\
\hline
\end{tabular}

Table 1 Enzyme inhibitory activities of 6-substituted Indazoles 11-20

We then explored the SAR at 4-position of the indazole ring. With the trifluoromethyl group fixed at 6-position of the indazole, we synthesized a small library of compounds using the route shown in Scheme $2 .{ }^{14}$ In order to efficiently evolve these fragments into lead compounds and maintain good physicochemical properties, we kept the $\mathrm{MW} \leq 350$ and $\operatorname{cog} \mathrm{P}<3$ for this library of compounds.<smiles>FC(F)(F)c1cc(Br)c2cc[nH]c2c1</smiles>
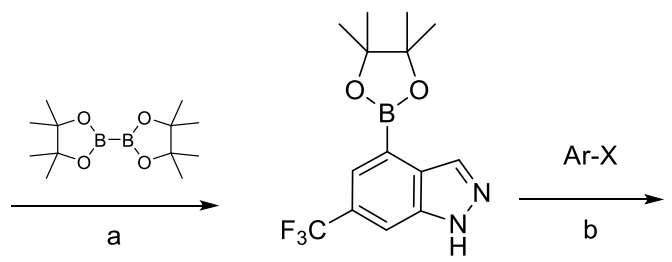<smiles>FC(F)(F)c1cc(Br)c2cn[nH]c2c1</smiles>

Scheme 2 (a) $\mathrm{PdCl}_{2}$ (dppf), $\mathrm{KOAc}, 100^{\circ} \mathrm{C}$; (b) $\mathrm{PdCl}_{2}(\mathrm{dppf}), \mathrm{Na}_{2} \mathrm{CO}_{3}$, microwave, $130^{\circ} \mathrm{C}$

Table 2 Enzyme inhibitory activities of 6-substituted Indazoles 21-30

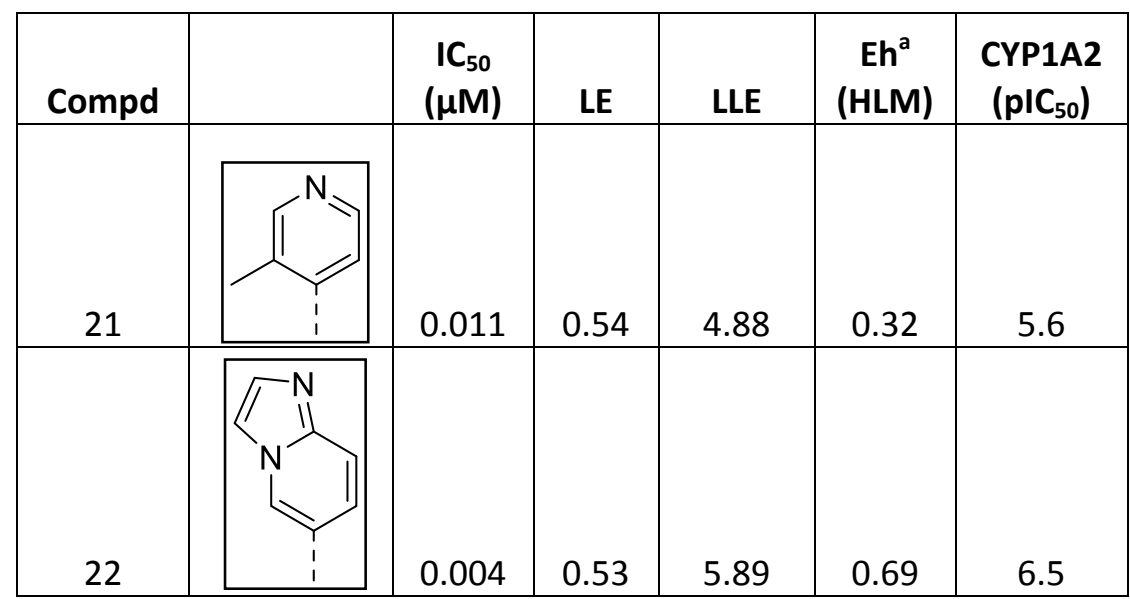




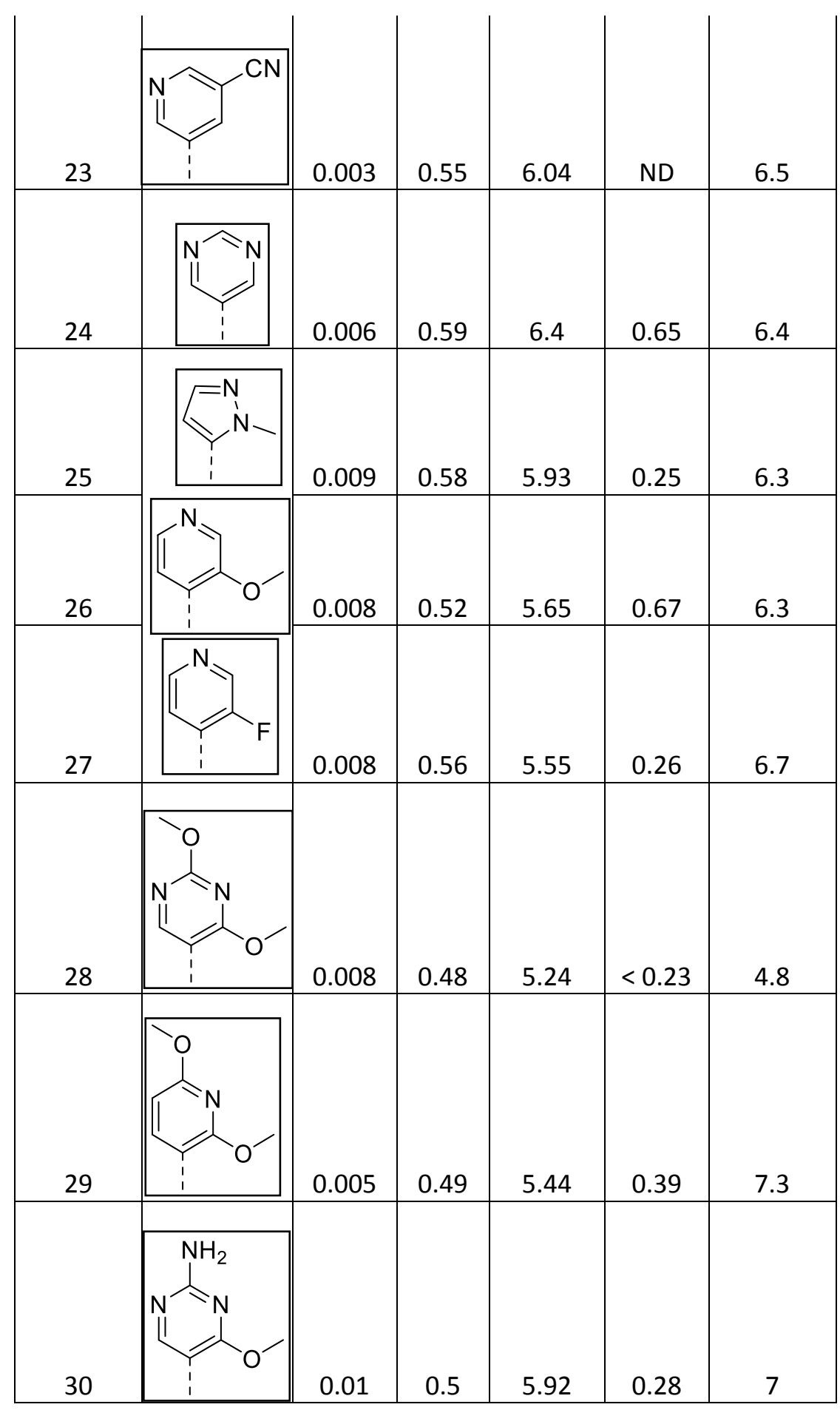

a) Stability in human liver microsomes at $1 \mu \mathrm{M}$. Data reported as extraction ratios.

In general, aryl/heteroaryl groups were well tolerated and modifications at position 4 generated compounds with low nM potency and good LLE. Analyzing the data for this library of compounds we observed that an ortho substituent on the 4-aryl group improved the human liver microsome stability (HLM) of these compounds vs an unsubstituted analog (Table 2). Presumably the ortho substituent puts the 4-aryl group out of plane with the indazole ring and potentially prevents binding to microsomes. Most of the compounds in this library inhibited CYP1A2 possibly due to their low molecular weight. ${ }^{15}$

A co-xtal structure of compound $\mathbf{2 1}$ bound to MetAP2 was subsequently generated and it confirms our proposed binding mode (Fig. 4).${ }^{16}$ As predicted the $\mathrm{N} 2$ of the indazole ring directly chelates to one of the metal ions while the $\mathrm{N} 1$ of the Indazole ring forms a water mediated H-bond with the second metal ion in the active site of MetAP2. The trifluoromethyl group on the Indazole ring fills the adjacent hydrophobic site while the pyridyl group occupies the narrow hydrophobic cleft between Tyr444 and His339. 


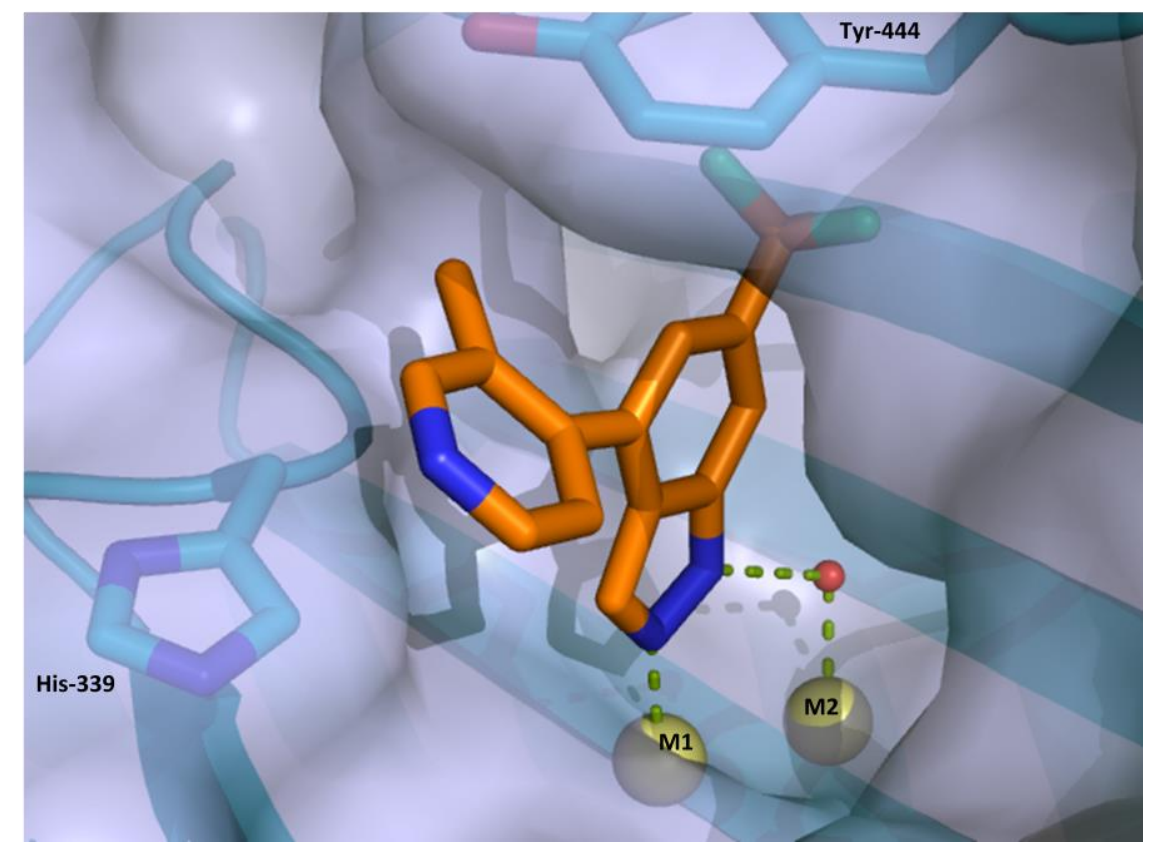

Fig. 4 Co-crystal of compound 21 bound to MetAP2

Insertion of a linker (ether, amino or amide) between the indazole ring and the aryl ring at position 4 of indazole reduced potency by > 10 fold (data not reported). With a goal of improving ADME properties while maintaining enzyme and cellular potency, ${ }^{17}$ the next set of analogs were synthesized with an ortho substituent on the aryl/heteroaryl group at the 4-position of the indazole ring.

\begin{tabular}{|c|c|c|c|c|c|c|c|}
\hline Compd & $\begin{array}{c}\mathrm{IC}_{50} \\
(\mu \mathrm{M})\end{array}$ & $\begin{array}{c}\text { Eh } \\
(\mathrm{HLM})\end{array}$ & $\begin{array}{c}\text { CYP1A2 } \\
(\mathrm{pIC50)}\end{array}$ & LE & LLE & $\begin{array}{c}\mathrm{EC}_{50} \\
(\mu \mathrm{M})\end{array}$ \\
\hline 31 & & & & & & \\
\hline
\end{tabular}




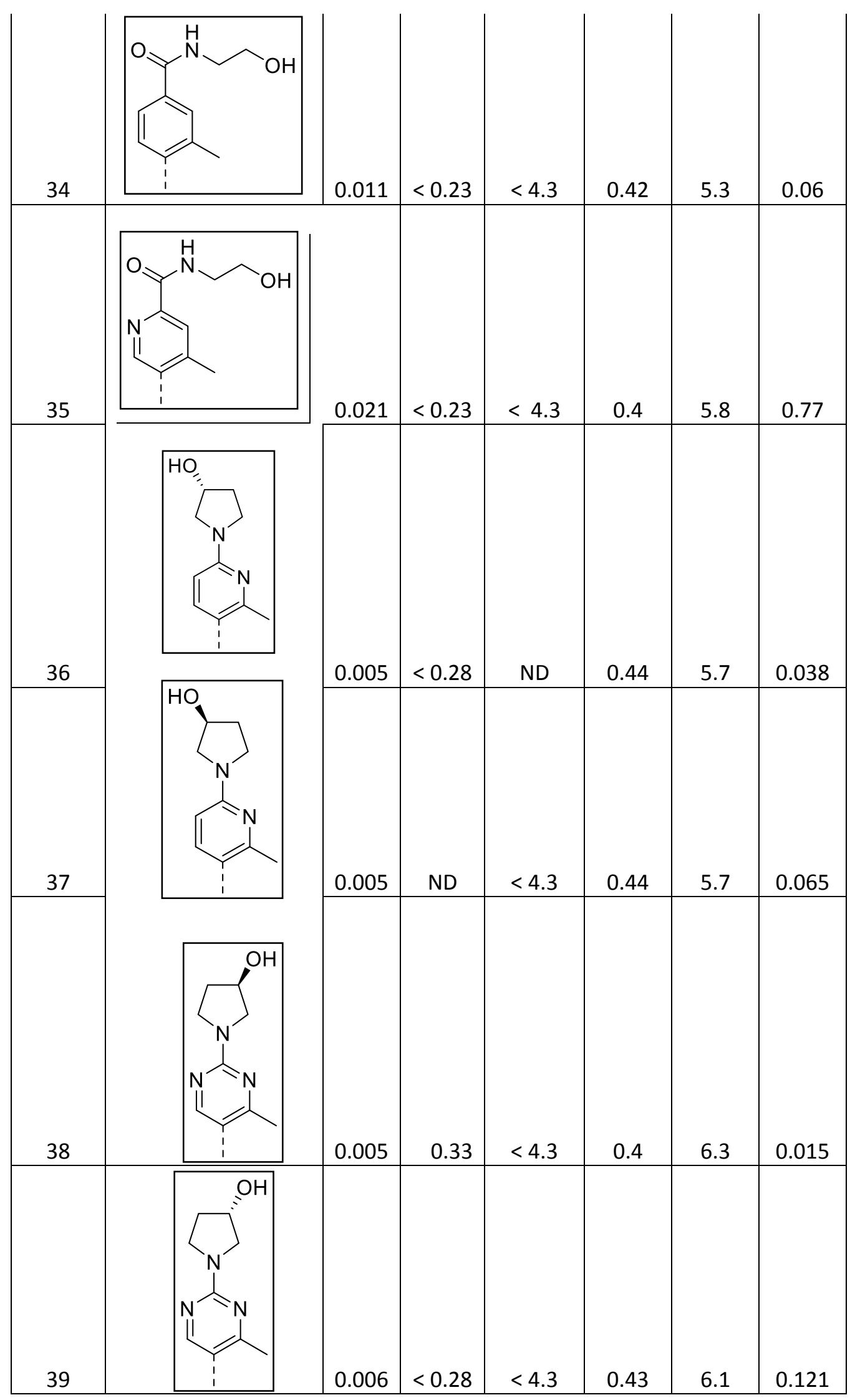

Table 3: Enzyme inhibitory activities of 6-substituted Indazoles 31-39

As can be seen from Table 3, several compounds achieve good enzyme and cellular potency, reduced potency against CYP1A2 and acceptable stability in HLM. We then selected compounds based on their potency and ADME profiles to be evaluated in a PK study. Compounds were administered to DIO mice and /or SD-rats at oral doses of $5 \mathrm{mg} / \mathrm{Kg}$ and iv doses of $1 \mathrm{mg} / \mathrm{kg}$. Compound 38 exhibited good stability in human hepatocytes $(\mathrm{Eh}=0.12)$ and its mouse pharmacokinetic profile was characterized by good oral 
exposure $(\mathrm{AUC}=15084 \mathrm{ng} * \mathrm{~h} / \mathrm{ml})$, a half-life of $2 \mathrm{~h}$, clearance of $18 \mathrm{~mL} / \mathrm{min} / \mathrm{Kg}$, volume of distribution of $1.25 \mathrm{~L} / \mathrm{Kg}$ and an oral bioavailability of $58 \%$.

Based on this, $\mathbf{3 8}$ was selected for further evaluation in a mouse model of obesity. A robust and sustainable dose-dependent body weight loss (BWL) was observed when DIO mice were dosed orally for 28 days at 3,10 and $30 \mathrm{mg} / \mathrm{kg}$ qd (Fig.5).

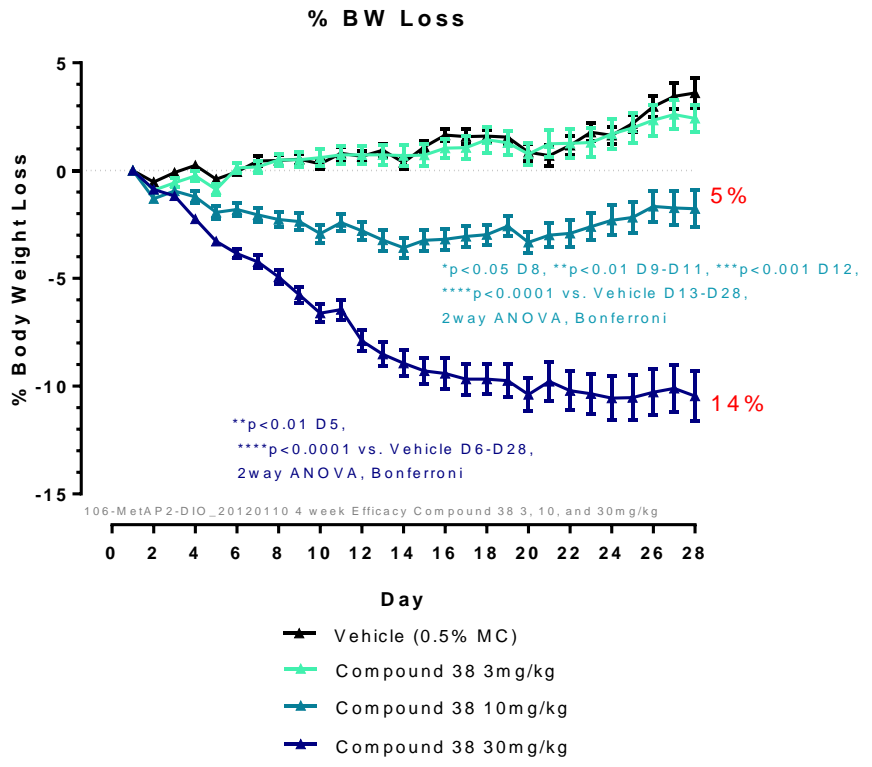

Fig. 5 BWL following oral administration of $\mathbf{3 8}$ in DIO mice

Compound 38 was evaluated in a Ricerca Comprehensive Pharmacological Profile panel including 100 biological targets (GPCRs, ion chanels, transporters and enzymes) and a panel of proteases and was found to have a clean selectivity profile at $10 \mu \mathrm{M}(<50 \%$ inhibition).

In conclusion, while we were unable to obtain co-xtal structures with fragments from this scaffold, the absence of a co-crystal structure did not hinder progression. Elaboration based on a predicted binding mode of the fragment was helped by an SAR by catalog approach. Notably, using this approach we were able to evolve the initial fragment hit into relatively compact lead compounds with high LLE and a > 350-fold gain in potency. The resulting lead compound $\mathbf{3 8}$ is a novel, potent, selective, reversible MetAP2 inhibitor which is efficacious in animal models for obesity.

\section{Acknowledgements}

We acknowledge Sean Murphy for Spotfire analysis, the ADME group for generating the microsomal and solubility data, Jennifer Matuszkiewicz for helping to generate the cellular data, and Lisa Rahbaek for generating the in vivo PK data. The staff of the Berkeley Center for Structural Biology is gratefully acknowledged for support of beam line 5.0.3 at the Advanced Light Source. The Advanced Light Source is supported by the Director, Office of Science, Office of Basic Energy Sciences, of the U.S. Department of Energy under Contract No. DE-AC02-05CH11231.

\section{References and Notes}

1. (a) Li, X.; Chang, Y.-H. Proc. Natl. Acad. Sci. U.S.A.1995, 92, 12357; (b) Arfin, S. T.; Kendall, R. L.; Hall, L.; Weaver, L. H.; Stewart, A. T.; Matthews, B. W.; Bradshaw, R. A. Proc. Natl. Acad. Sci. U.S.A. 1995, 92, 7714.

2. Serero, A.; Giglione, C.; Sardini, A.; Martinez-Sanz, J.; Meinnel, T. J. Biol. Chem. 2003, 278, 52953.

3. (a) Sin, N.; Meng, L.; Wang, M. Q.; Wen, J. J.; Bormann, W. G.; Crews, C. M. Proc. Natl. Acid. Sci. U.S.A. 1997, 94, 6099; (b)

Griffith, E. C.; Su, Z.; Turk, B. E.; Chen, S.; Chang, Y. H.; Wu, Z.; Biemann, K.; Liu, J. O. Chem. Biol. 1997, 4, 461.

4. S.-Q. Yin, J.-J. Wang, C.-M. Zhang and Z.-P. Liu. Current Medicinal Chemistry, 2012, 19, 1021-1035.

5. Maria A. Rupnick, Dipak Panigrahy, Chen-Yu Zhang, Susan M. Dallabrida, Bradford B. Lowell, Robert Langer,and M. Judah Folkman. Proc. Natl. Acad. Sci. U.S.A. 2002, 99, 10730-10735.

6. Kim, D.D ; Krishnarajah, J.; Lillioja, S.; de Looze, F.; Marjason, J.; Proietto, J.; Shakib, S.; Stuckley, B.G.A.; Vath, J.E ; Hughes, T.E.; Diabetes, Obesity and Metabolism; 2015, 1-7.

7. Erlanson, D. A. Top. Curr. Chem. 2012, 317, 1-32. 
8. Wang, J.; Sheppard, G.S.; Lou, P.; Kawai, M.; Park, C.; Egan, D. A.; Schneider, A.; Bouska, J.; Lesniewski, R.; Henkin, J. Biochemistry, 2004, 328, 131.

9. $\mathrm{ApIC}_{50}=-\log ([$ inhibitor $] /(\mathrm{Vo} / \mathrm{V}-1))$ where $\mathrm{Vo}=$ enzyme activity in the absence of inhibitor and $\mathrm{V}=$ enzyme activity in the presence of inhibitor

10. PDB for compound 3 is 1 R58

11. Molecular Operating Environment (MOE) software, MOE, Chemical Computing Group Inc.

12. PDB for compound $\mathbf{5}$ is $5 \mathrm{JHU}$

13. Hopkins, A. L.; Groom, C. R.; Alex, A. Ligand Efficiency: A Useful Metric for Lead Selection. Drug Discovery Today 2004, 9 , 430-431.

14. Patent applications describing our MetAP2 inhibitors have been published. Full experimental procedures for all analogs in this paper are contained within the patent application: WO 2013/130855.

15. Stefaan Sansen, Jason K. Yano, Rosamund L. Reynald, Guillaume A. Schoch, Keith J. Griffin, C. David Stout, and Eric F. Johnson; J.Biol.Chem. 2007, 14348-14355

16. PDB for compound 21 is $5 \mathrm{JI} 6$

17. The HUVEC assay used is not a proliferation assay, but rather verifies target engagement by measurement of the accumulation of N-Met 14-3-3 $\gamma$ which is a client protein of MetAP2. Details on the cell assay are contained within the patent application: WO 2013/130855 

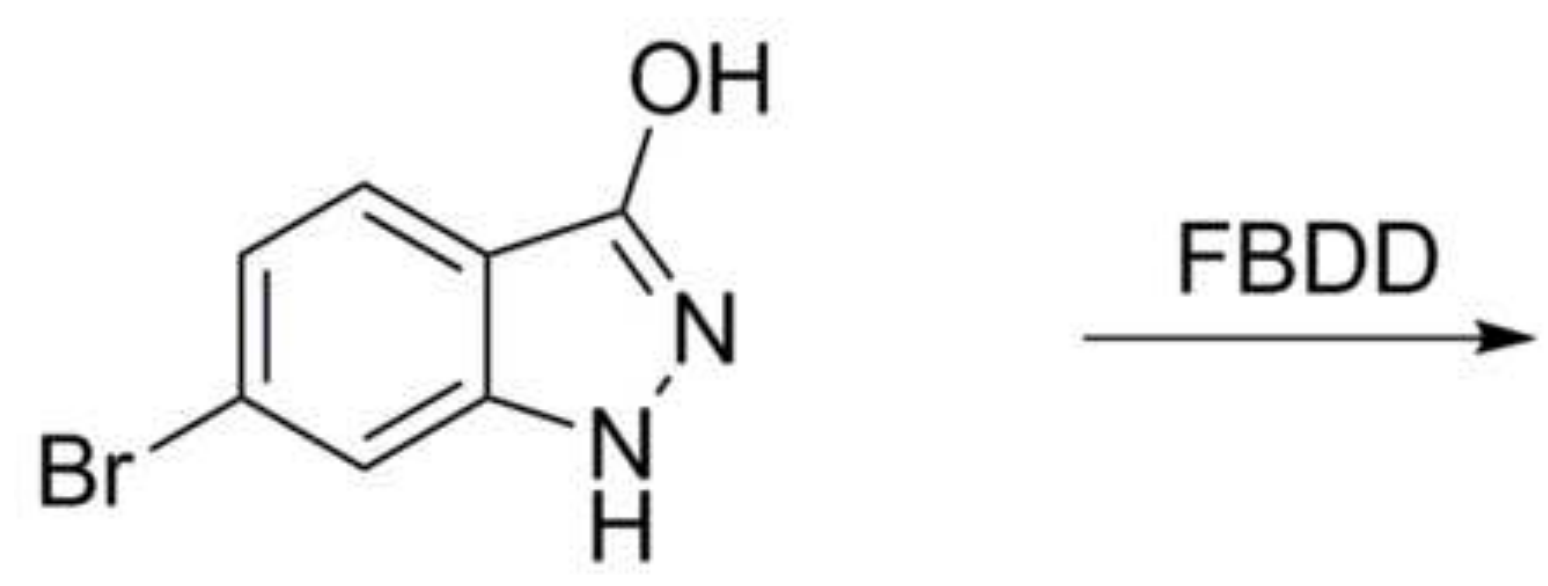

6

IC50 $2.8 \mu \mathrm{M}$ LE 0.69

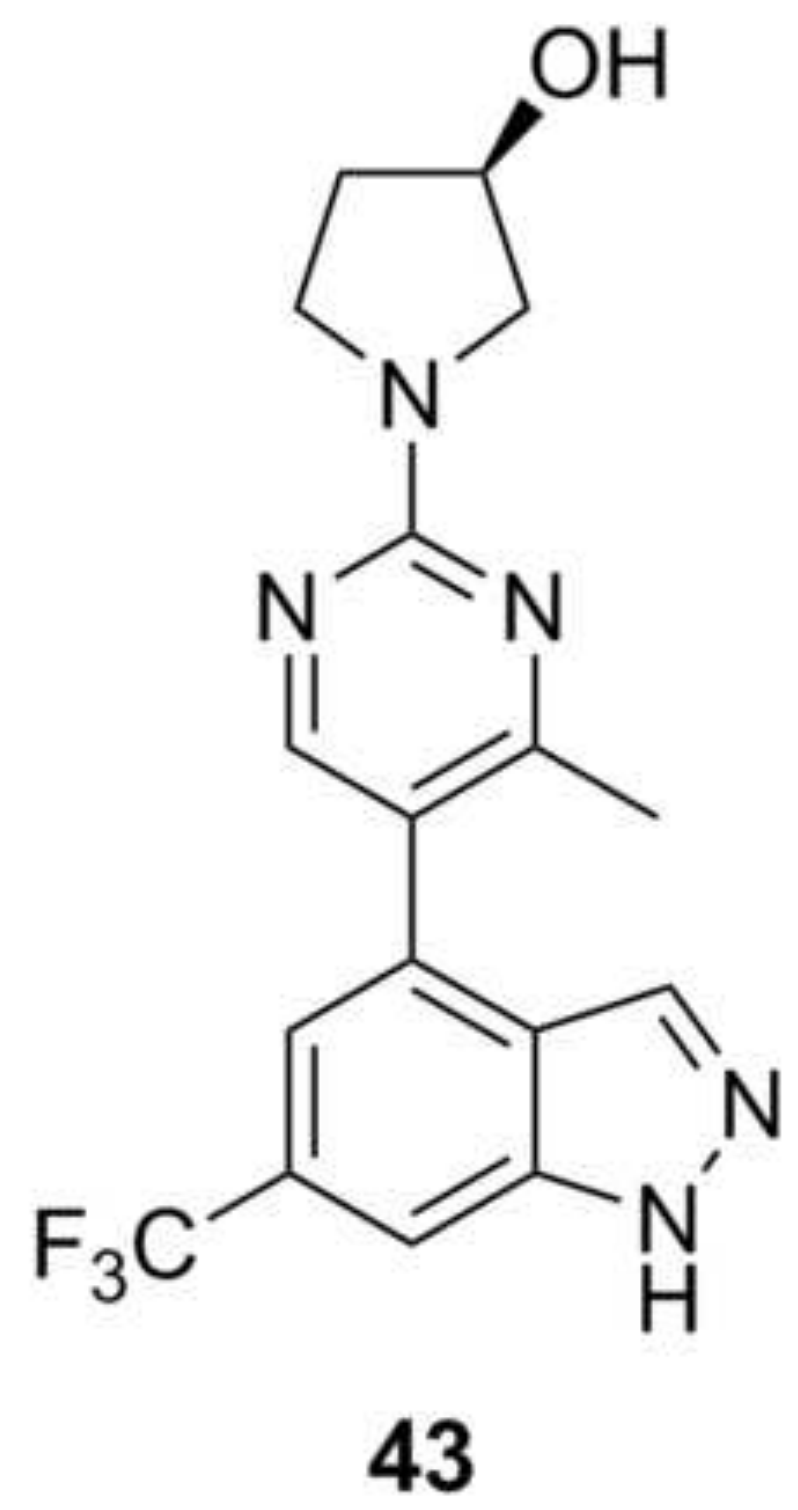

IC50 $5 \mathrm{nM}$ LE 0.43 